\author{
Multidisciplinary \\ SCIENTIFIC JOURNAL \\ OF MARITIME RESEARCH
}

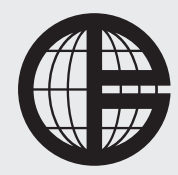

University of Rijeka

FACULTY OF MARITIME STUDIES

\author{
Multidisciplinarni \\ znanstveni časopis \\ POMORSTVO
}

https://doi.org/10.31217/p.33.1.8

\title{
Exergy analysis of marine steam turbine labyrinth (gland) seals
}

\author{
Ivan Lorencin, Nikola Anđelić, Vedran Mrzljak, Zlatan Car
}

University of Rijeka, Faculty of Engineering, Vukovarska 58, 51000 Rijeka, Croatia, e-mail: ilorencin@riteh.hr; nandelic@riteh.hr; vedran.mrzljak@riteh.hr; zlatan.car@riteh.hr

\section{ABSTRACT}

The paper presents an exergy analysis of marine steam turbine labyrinth (gland) seals - an inevitable component of any marine steam turbine cylinder, in three different operating regimes. Throughout labyrinth seals, steam specific enthalpy can be considered as a constant because the results obtained by this assumption do not deviate significantly from the results of complex numerical models. Changes in labyrinth seals exergy efficiency and specific exergy destruction are reverse proportional. The analyzed labyrinth seals have high exergy efficiencies in each observed operating regime at the ambient temperature of $298 \mathrm{~K}$ (above 92\%), what indicates seals proper operation. An increase in the ambient temperature resulted with a decrease in labyrinth seals exergy efficiency, but even at the highest observed ambient temperature of $318 \mathrm{~K}$, seals exergy efficiency did not fall below $90.5 \%$ in each observed operating regime.

\section{ARTICLE INFO}

Original scientific paper

Received 10 May 2019

Accepted 4 June 2019

Key words:

Marine steam turbine

Gland seals

Exergy loss

Exergy efficiency

\section{Introduction}

Each marine steam turbine cylinder, regardless of its type, developed power and operation characteristics [1], has two labyrinth (gland) seals (front and rear) which are used to decrease pressure of steam leaked between turbine rotor and housing and which delivered that leaked steam (with decreased pressure) to the gland (sealing) steam condenser [2].

Cumulative steam mass flow rate lost through both labyrinth seals of each turbine cylinder has a small share in steam mass flow rate which enters into the turbine cylinder [3], therefore in some marine steam turbine analysis this leaked mass flow rate can be neglected without significant influence on the results of the analysis [4]. A detail analysis of any steam turbine cylinder must be performed by taking into account steam mass flow rate lost (leaked) through its labyrinth (gland) seals [5].

A detail of front labyrinth (gland) seals from marine high-pressure steam turbine cylinder is presented in Fig. 1. This cylinder is part of the whole main propulsion steam turbine from LNG carrier, which complete analysis can be found in [6]. However, the presented analysis does

\begin{tabular}{|c|c|}
\hline \multicolumn{2}{|r|}{ NOMENCLATURE } \\
\hline \multicolumn{2}{|r|}{ Abbreviations: } \\
\hline $\mathrm{BF}$ & Bulk Flow \\
\hline CFD & Computational Fluid Dynamics \\
\hline \multicolumn{2}{|r|}{ Latin Symbols: } \\
\hline$\dot{E}$ & the total exergy of a flow, $\mathrm{kW}$ \\
\hline$h$ & specific enthalpy, kJ/kg \\
\hline$\dot{m}$ & mass flow rate, $\mathrm{kg} / \mathrm{s}$ \\
\hline$p$ & pressure, bar \\
\hline$P$ & power, kW \\
\hline$\dot{Q}$ & heat transfer, kW \\
\hline$S$ & specific entropy, $\mathrm{kJ} / \mathrm{kg} \cdot \mathrm{K}$ \\
\hline$T$ & temperature, $\mathrm{K}$ \\
\hline$\dot{X}_{\text {heat }}$ & exergy transfer by heat, kW \\
\hline \multicolumn{2}{|r|}{ Greek symbols: } \\
\hline$\varepsilon$ & specific exergy, $\mathrm{kJ} / \mathrm{kg}$ \\
\hline$\eta$ & efficiency, \% \\
\hline \multicolumn{2}{|r|}{ Subscripts: } \\
\hline 0 & ambient state \\
\hline $\mathrm{D}$ & destruction (loss) \\
\hline ex & exergy \\
\hline in & inlet (input) \\
\hline out & outlet (output) \\
\hline
\end{tabular}


not include steam mass flow rates leaked through a labyrinth (gland) seals of any marine turbine cylinder or other details related to the labyrinth (gland) seals.

Along with gland seals at each steam turbine cylinder inlet and outlet, inside the turbine cylinder is mounted many labyrinth seals. At each steam turbine stage (which consist of stator and rotor blades) labyrinth seals are mounted under the stator blades (between stator part and rotor) and above the rotor blades (between the rotor blades and turbine housing). The function of all labyrinth seals inside the steam turbine, at each turbine stage, is to reduce steam leakage between stator and rotor parts and returning leaked steam in main steam flow (main steam flow passes through channels between all stator and rotor blades at each turbine stage).

Measurements of the leaked steam flow rate at the labyrinth seals inside the turbine are extremely hard to obtain because it will require complex measuring equipment mounted at each part of each turbine stage - what is only theoretically possible at experimental steam turbines, surely not on the steam turbines in the real exploitation. However, in the literature [8] can be found mathematical model for calculation of leaked steam flow rate at such labyrinth seals inside the turbine. On the one side, this mathematical model involves many constants, which do not have to be universally applicable. On the other side, this mathematical model can be used as an indicator of the leaked steam flow rate (and simultaneously lost power) at each turbine stage from the turbine inlet to the outlet.

An exergy analysis of steam labyrinth (gland) seals is rare in the scientific and professional literature. Therefore, in this paper is performed an exergy analysis of stepped steam labyrinth seals by using steam operating parameters at seals inlet and outlet. Analysis is performed for three different operating regimes. In each operating regime, steam pressure and temperature decrease, as well as change in steam specific entropy through labyrinth seals are presented. It is investigated labyrinth seal specific exergy destructions and exergy efficiencies in each operating regime. At the end, it was analyzed the influence of the ambient temperature change on labyrinth seal specific exergy destruction and exergy efficiency in each operating regime.

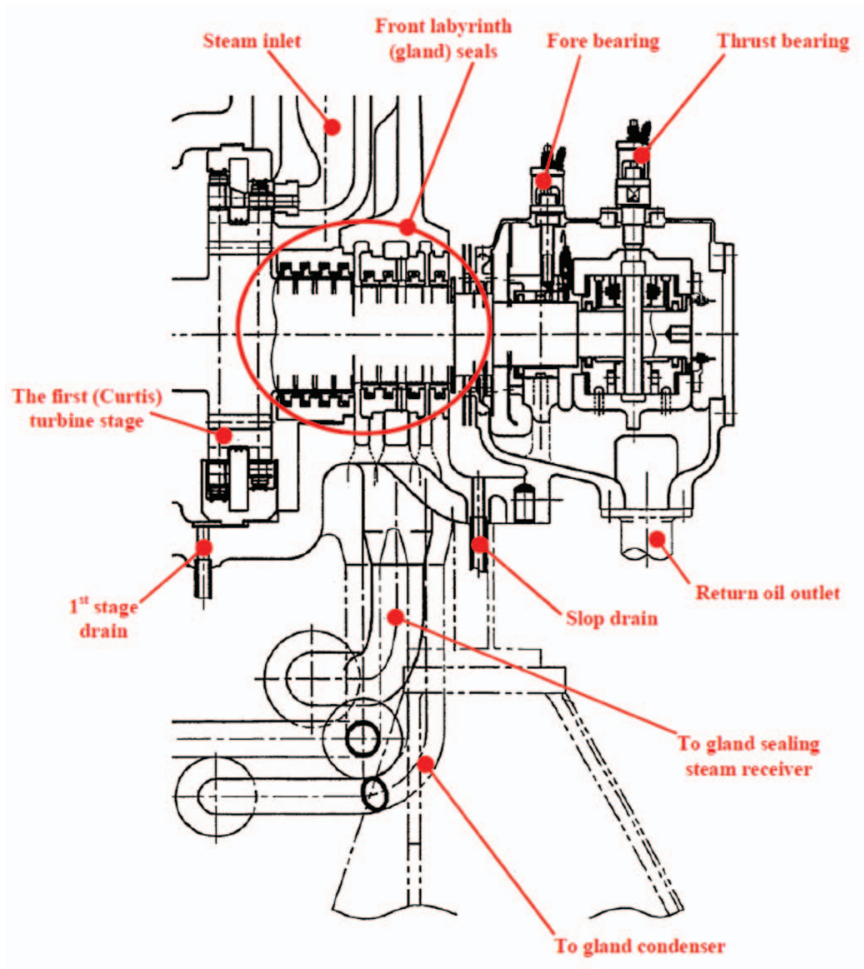

Fig. 1 Front part cross-section of marine high-pressure steam turbine cylinder along with the labyrinth (gland) seals [7]

\section{Analyzed steam turbine labyrinth (gland) seals characteristics and operation principle}

Steam labyrinth (gland) seals are mounted at each steam turbine cylinder inlet and outlet. One part of the steam mass flow rate, which enters into the turbine is not flowing through the turbine stages, but it is leaking between turbine rotor and housing and has to be stopped with front turbine labyrinth (gland) seals, Fig. 1. The front turbine labyrinth seals will reduce leaked steam pressure and after the seals, leaked steam is delivered to the gland steam condenser. The function of the rear labyrinth (gland) seals of any steam turbine cylinder is the same as the function of front labyrinth seals with the difference that rear gland seals decreases the pressure of leaked

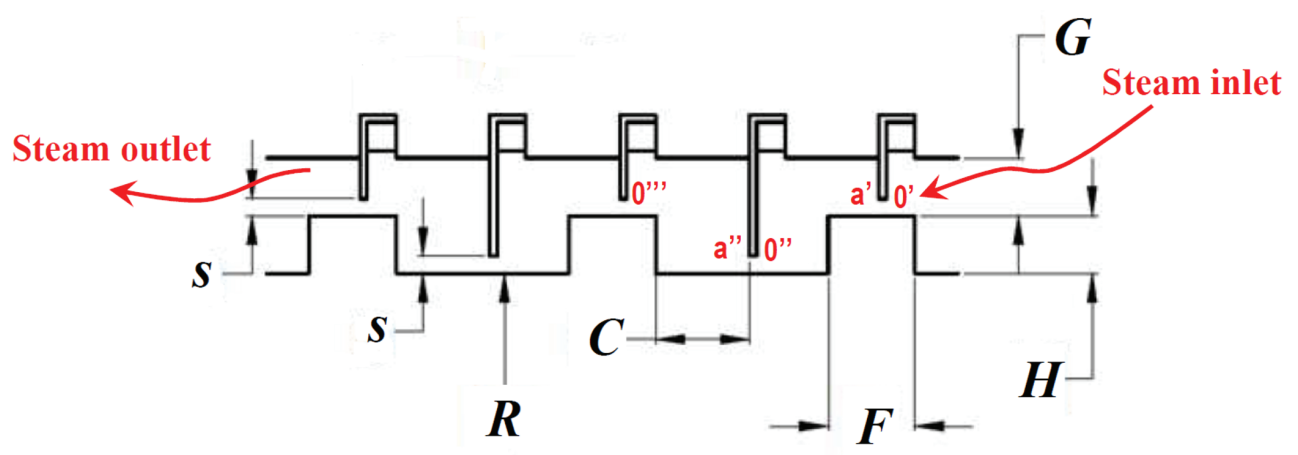

Fig. 2 Stepped labyrinth (gland) seals detail with marked steam flow inlet and outlet Source: Authors 
Table 1 Analyzed labyrinth (gland) seals main dimensions and characteristics [9]

\begin{tabular}{|l|c|c|}
\hline \multicolumn{1}{|c|}{ Description } & Mark in Fig. 2 & Dimension \\
\hline Shaft radius & $\boldsymbol{R}$ & $400 \mathrm{~mm}$ \\
\hline Radial clearance & $\boldsymbol{G}$ & $0.8 \mathrm{~mm}$ \\
\hline Steps-to-casing radial distance & $\boldsymbol{H}$ & $2.5 \mathrm{~mm}$ \\
\hline Steps height & $\boldsymbol{F}$ & $2.0 \mathrm{~mm}$ \\
\hline Steps width & $\boldsymbol{C}$ & $2.0 \mathrm{~mm}$ \\
\hline J-strip-to-step axial distance & \multicolumn{2}{|c|}{$3.7 \mathrm{~mm}$} \\
\hline J-strips number & \multicolumn{2}{|c|}{10} \\
\hline Rotor steps number & \multicolumn{2}{|c|}{} \\
\hline
\end{tabular}

steam after it expanded through turbine stages. Steam after rear gland seals is also delivered to the gland steam condenser.

Labyrinth seals can be straight and stepped type [8]. In this paper is performed exergy analysis of stepped type steam labyrinth seals which detail is presented in Fig. 2, while the main dimensions and characteristics of the whole analyzed labyrinth seals are shown in Table 1.

Steam turbine labyrinth (gland) seals are steam power plant component which energy analysis will result with energy loss equal to zero and with energy efficiency equal to $100 \%$. Therefore, for steam turbine labyrinth seals, only the exergy analysis can be the relevant one. This conclusion can be confirmed by labyrinth seals operation principle presented in Fig. 3. Another steam plant component for which is valid this conclusion is a pressure reducing valve (throttle valve) [10], [11].

Steam mass flow rate at the labyrinth seals inlet is the same as steam mass flow rate at the labyrinth seals outlet, Fig. 2, because through seals steam mass flow leakage does not occur. At the labyrinth seals inlet, steam has operating parameters marked with 0 ' in Fig. 2 and Fig. 3. While passing through the first gap (the first radial clearance), steam expanded to lower pressure after gap to point a' (steam expansion resulted with an increase in steam kinetic energy). In the chamber (cavity) after the first gap, steam kinetic energy is completely transferred to heat

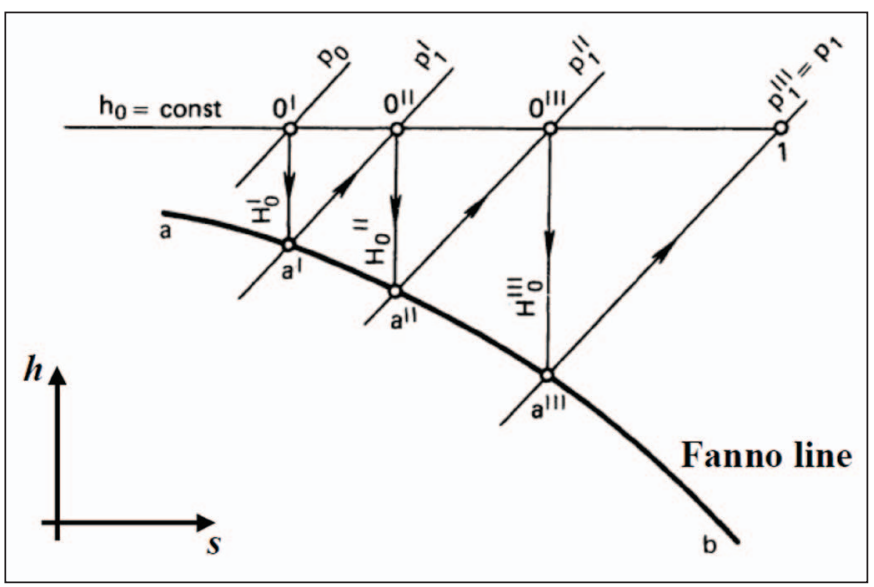

Fig. 3 Labyrinth (gland) seals operating principle in $h$-s diagram [8] (isobaric temperature increase from a' to 0"). At the entrance of the second gap (point 0 ") steam has an identical specific enthalpy as at the entrance of the first gap (point 0 '). This process is repeated through the entire labyrinth seals, until steam exits the last seals gap (seals outlet). From the labyrinth (gland) seals outlet, steam is delivered to the gland steam condenser (sealing steam condenser) [2], [12]. The gland steam condenser is usually the first feed-water heater (feed-water heating with steam which passes through labyrinth seals of all turbine cylinders in the power plant) mounted after the main condenser [13].

As presented in Fig. 3, steam specific enthalpy is the same at labyrinth seals inlet and outlet (change of steam specific enthalpy due to heat losses can be neglected) [8]. Fanno line shown in Fig. 3 represents constant steam mass flow rate throughout the labyrinth seals.

Due to the same steam mass flow rate and steam specific enthalpy at labyrinth seals inlet and outlet, the total energy of a steam flow through seals is not changed, what confirms conclusion from the beginning of this paragraph.

\section{Exergy analysis equations}

Exergy analysis of any control volume or a system, as well as of analyzed labyrinth (gland) seals, is defined by the second law of thermodynamics [14]. Unlike energy analysis, exergy analysis of any control volume or a system is dependable on the conditions of the ambient in which control volume (or system) operates [15], [16].

\subsection{Overall exergy analysis equations of a control volume or system}

If the leakage of operating fluid does not occur during control volume or system operation, mass flow rate balance for any control volume or system can be defined as noted in [17] and [18]:

$$
\sum \dot{m}_{\text {in }}=\sum \dot{m}_{\text {out }}
$$

For a control volume (or system) in steady state operation, main exergy balance equation, according to [19] can be defined as:

$$
\sum \dot{m}_{\text {in }} \cdot \varepsilon_{\text {in }}+\dot{X}_{\text {heat }}=\sum \dot{m}_{\text {out }} \cdot \varepsilon_{\text {out }}+P+\dot{E}_{\text {ex }, \mathrm{D}}
$$


with a note that in the above equation potential and kinetic energy are disregarded, as proposed in [20].

In the Eq. 2, $\dot{X}_{\text {heat }}$ is the cumulative exergy transfer by heat at the temperature $T$, which is according to [21] and [22] defined with the following expression:

$$
\dot{X}_{\text {heat }}=\sum\left(1-\frac{T_{0}}{T}\right) \cdot \dot{Q}
$$

In [23] and [24] can be found a definition of specific exergy from the Eq. 2:

$$
\varepsilon=\left(h-h_{0}\right)-T_{0} \cdot\left(s-s_{0}\right)
$$

The total exergy of a fluid flow is defined as [25]:

$$
\dot{E}_{\mathrm{ex}}=\dot{m} \cdot \varepsilon=\dot{m} \cdot\left[\left(h-h_{0}\right)-T_{0} \cdot\left(s-s_{0}\right)\right]
$$

The general definition of any control volume or system exergy efficiency, according to [26] and [27] can be described by an equation:

$$
\eta_{\text {ex }}=\frac{\text { Exergy output }}{\text { Exergy input }}
$$

\subsection{Equations for labyrinth (gland) seals exergy analysis}

For the analyzed steam labyrinth (gland) seals, the steam mass flow rate at the seals inlet and outlet is the same, Fig. 2:

$$
\dot{m}_{\text {in }}=\dot{m}_{\text {out }}
$$

Labyrinth seals exergy power input is:

$$
\dot{E}_{\text {ex,in }}=\dot{m}_{\text {in }} \cdot \varepsilon_{\text {in }}
$$

while exergy power output of the analyzed labyrinth seals is:

$$
\dot{E}_{\text {ex }, \text { out }}=\dot{m}_{\text {out }} \cdot \varepsilon_{\text {out }}
$$

Labyrinth seals exergy power loss (exergy destruction):

$\dot{E}_{\text {ex }, \mathrm{D}}=\dot{E}_{\text {ex,in }}-\dot{E}_{\text {ex }, \text { out }}=\dot{m}_{\text {in }} \cdot \varepsilon_{\text {in }}-\dot{m}_{\text {out }} \cdot \varepsilon_{\text {out }}=$

$=\dot{m}_{\text {in }} \cdot\left(\varepsilon_{\text {in }}-\varepsilon_{\text {out }}\right)$

If the steam mass flow rate through the seals is not known (as in this analysis), specific exergy power loss (specific exergy destruction) of the analyzed labyrinth seals is defined as:

$\dot{E}_{\text {ex,D, specific }}=\varepsilon_{\text {in }}-\varepsilon_{\text {out }}$

Analyzed labyrinth seals exergy efficiency:

$$
\eta_{\text {ex }}=\frac{\dot{E}_{\text {ex }, \text { out }}}{\dot{E}_{\text {ex,in }}}=\frac{\dot{m}_{\text {out }} \cdot \varepsilon_{\text {out }}}{\dot{m}_{\text {in }} \cdot \varepsilon_{\text {in }}}=\frac{\varepsilon_{\text {out }}}{\varepsilon_{\text {in }}}
$$

\section{Steam operating parameters at the labyrinth (gland) seals inlet and outlet}

Steam operating parameters at the labyrinth seals inlet and outlet are found in [9] and presented in Table 2. Steam pressure at the labyrinth seals inlet is little lower than the maximum steam pressure in marine steam power plants with steam re-heating [28]. At the seals inlet it is known steam temperature and pressure, while at seals outlet is known only steam pressure. Additional steam operating parameter required for calculating all the other operating parameters at seals outlet is the same steam specific enthalpy throughout gland seals, Fig. 3. Steam specific enthalpies and specific entropies presented in Table 2 at seals inlet and outlet were calculated by using NistREFPROP 9.0 software [29].

Steam specific exergies are calculated by using Eq. 4. Specific exergy of any fluid flow is dependable on the conditions of the ambient in which fluid operates. Steam specific exergies presented in Table 2 was calculated for the

Table 2 Steam operating parameters at the analyzed labyrinth seals inlet and outlet

\begin{tabular}{|c|c|c|c|c|c|}
\hline \multicolumn{6}{|c|}{ Labyrinth seals inlet } \\
\hline No. & Pressure (bar)* & Temperature (K)* & $\begin{array}{c}\text { Specific enthalpy } \\
\mathbf{( k J / k g )}\end{array}$ & $\begin{array}{c}\text { Specific entropy (kJ/ } \\
\mathbf{k g} \cdot \mathbf{K})\end{array}$ & $\begin{array}{c}\text { Specific exergy (kJ/ } \\
\mathbf{k g})\end{array}$ \\
\hline Test 1 & 87.4 & 698 & 3194.3 & 6.4097 & 1288.7 \\
\hline Test 2 & 87.6 & 698 & 3194.0 & 6.4083 & 1288.8 \\
\hline Test 3 & 19.5 & 698 & 3303.7 & 7.2213 & 1156.3 \\
\hline \multicolumn{7}{|c|}{ Labyrinth seals outlet } \\
\hline No. & Pressure (bar)* & Temperature (K) & $\begin{array}{c}\text { Specific enthalpy } \\
\text { (kJ/kg) }\end{array}$ & $\begin{array}{c}\text { Specific entropy (kJ// } \\
\mathbf{k g} \cdot \mathbf{K})\end{array}$ & $\begin{array}{c}\text { Specific exergy (kJ/ } \\
\mathbf{k g})\end{array}$ \\
\hline Test 1 & 40 & 664.65 & 3194.3 & 6.7412 & 1189.9 \\
\hline Test 2 & 70 & 686.30 & 3194.0 & 6.5015 & 1261.1 \\
\hline Test 3 & 10 & 691.55 & 3303.7 & 7.5244 & 1065.9 \\
\hline
\end{tabular}

* Steam operating parameters from [9] (other operating parameters from Table 2 were calculated with Nist-REFPROP 9.0 software [29]).

Source: Authors 
ambient state as proposed in [30] - for the ambient pressure of $1 \mathrm{bar}=0.1 \mathrm{MPa}$ and the ambient temperature of $25^{\circ} \mathrm{C}=298 \mathrm{~K}$.

\section{Validation of constant steam specific enthalpy assumption through a labyrinth (gland) seals}

In the [9] the same labyrinth seals are analyzed by a complex CFD (Computational Fluid Dynamics) and BF (Bulk Flow) numerical models, but the exergy analysis is not performed. Such complex analyses allow detail calculation of steam pressure and temperature in each labyrinth seal cavity (as presented in Table 1, analyzed labyrinth seals have 20 cavities) as well as calculation of the change in steam specific enthalpy throughout labyrinth seals.

Change in steam temperature through all cavities, for all three observed tests obtained by CFD and BF numerical models are presented in Fig. 4. For the exergy analysis of the same labyrinth seals, required steam temperatures for all three tests are steam temperatures at the labyrinth seals inlet and outlet. Assumption of the same steam specific enthalpy at labyrinth seals inlet and outlet (and neglecting of heat losses) resulted with a fact that calculated steam temperatures at the seals outlet (Table 2) vary from the ones obtained by a complex CFD and BF analyses as follows: for Test $1(+0.5 \mathrm{~K})$, for Test $2(-2 \mathrm{~K})$ and for Test $3(-3 \mathrm{~K})$, Fig. 4.

\section{The results of steam labyrinth (gland) seals exergy analysis with discussion}

Analyzed tests of the labyrinth seals were performed according to steam pressure decrease (steam pressure difference between seals inlet and outlet) - from the highest pressure decrease ( 47.4 bar - Test 1 ), up to middle pressure decrease (17.6 bar - Test 2) and finally to the lowest pressure decrease (9.5 bar - Test 3), Fig. 5. Simultaneously with the steam pressure decrease occurs steam temperature decrease (steam temperature difference between seals inlet and outlet), which is equal to $33.35 \mathrm{~K}, 11.70 \mathrm{~K}$ and $6.45 \mathrm{~K}$ for Test 1 , Test 2 and Test 3, Fig. 5.

As the vapor passing through the analyzed labyrinth seals, a specific entropy increase at each conducted test occur, therefore vapor specific entropy difference is calculated as a difference between labyrinth seals outlet and inlet. The difference between the specific entropy of the steam between the labyrinth seals and the inlet opening is the lowest in Test 2 and is $0.0932 \mathrm{~kJ} / \mathrm{kg} \cdot \mathrm{K}$, for Test 3 is equal to $0.3031 \mathrm{~kJ} / \mathrm{kg} \cdot \mathrm{K}$ and finally is the highest for Test 1 and amounts $0.3315 \mathrm{~kJ} / \mathrm{kg} \cdot \mathrm{K}$, Fig. 5. Change in steam specific entropy between labyrinth seals outlet and inlet is important for the steam specific exergy calculation and for entire labyrinth seals exergy analysis.

The change in steam specific entropy difference between analyzed labyrinth seals outlet and inlet (Fig. 5) defines seals specific exergy destruction change for the observed tests, Fig. 6. Labyrinth seals specific exergy destruction is the highest in Test $1(98.8 \mathrm{~kJ} / \mathrm{kg})$, the lowest in Test $2(27.7 \mathrm{~kJ} / \mathrm{kg})$, while in Test 3 it is equal to $90.4 \mathrm{~kJ} /$ kg, Fig. 6.

In general, the change in labyrinth seals specific exergy destruction is reverse proportional to change in seals exergy efficiency. Labyrinth seals exergy efficiency is the highest for Test $2(97.85 \%)$ where the seals specific exergy destruction is the lowest. When comparing Test 1 and Test 3 , regardless of the higher seals exergy destruction in Test 1 , seals exergy efficiency in Test 1 is slightly higher than in Test 3 (92.33\% in Test 1 and 92.18\% in Test 3), Fig. 6.

From the presented results, it can be concluded that the analyzed labyrinth seals have a high exergy efficiency, which exceeded $92 \%$ in all of the observed tests (for the ambient temperature of $298 \mathrm{~K}$ ).

In this paper is also investigated the impact of the ambient temperature change on the specific exergy destruction and exergy efficiency of the analyzed labyrinth seals. The ambient temperature is varied from $278 \mathrm{~K}\left(5^{\circ} \mathrm{C}\right)$ to $318 \mathrm{~K}\left(45^{\circ} \mathrm{C}\right)$.

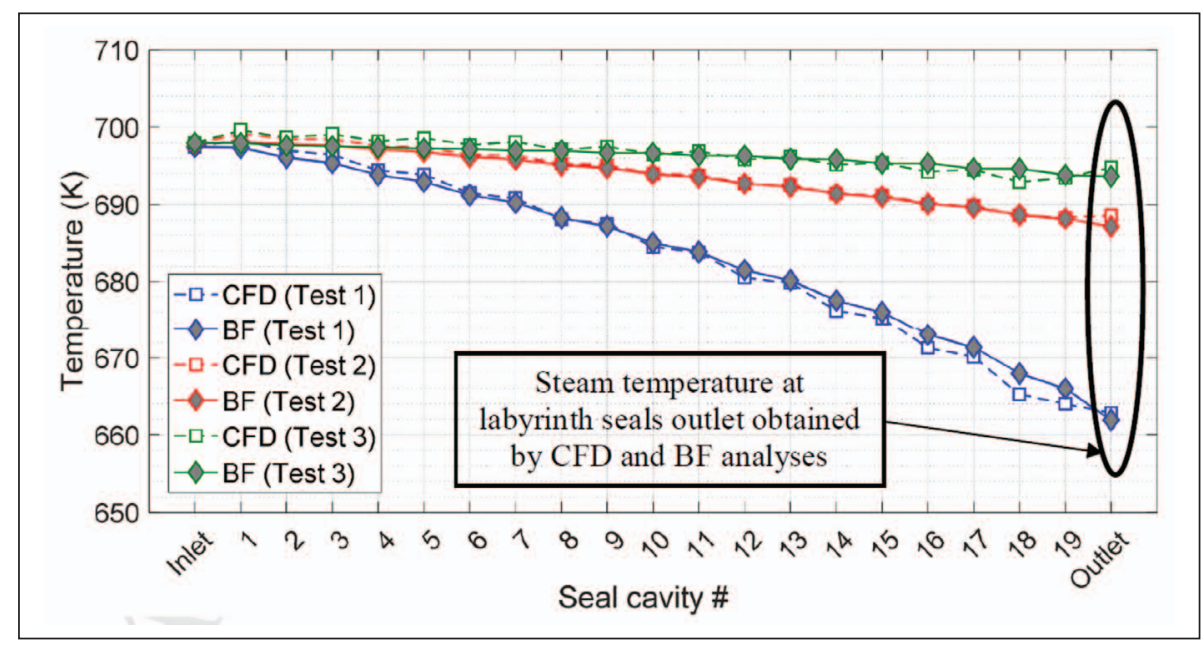

Fig. 4 The steam temperature at labyrinth seals outlet obtained by a complex CFD and BF analyses [9] 


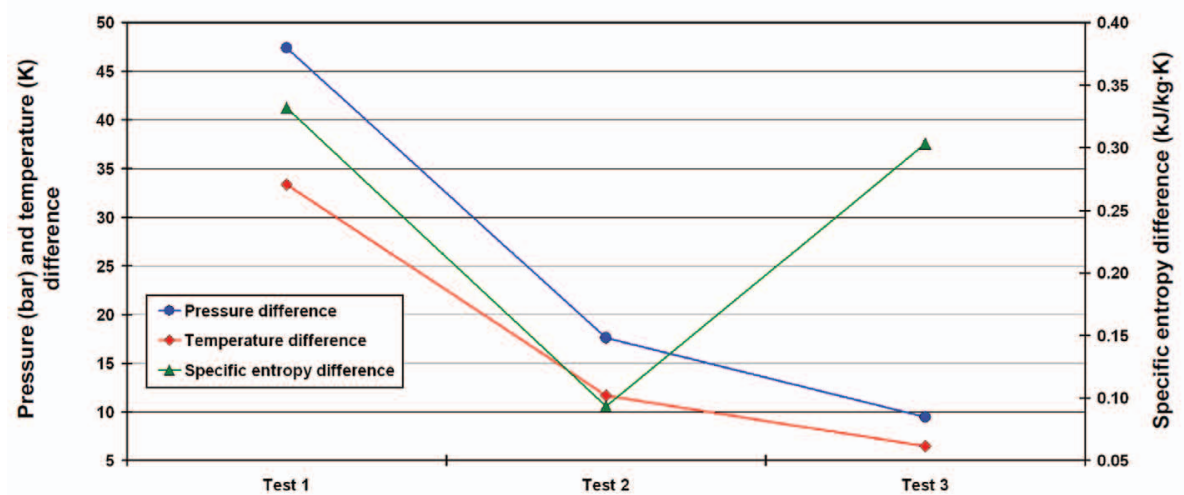

Fig. 5 Differences in steam pressure, temperature and specific entropy between labyrinth seals inlet and outlet for three observed tests Source: Authors

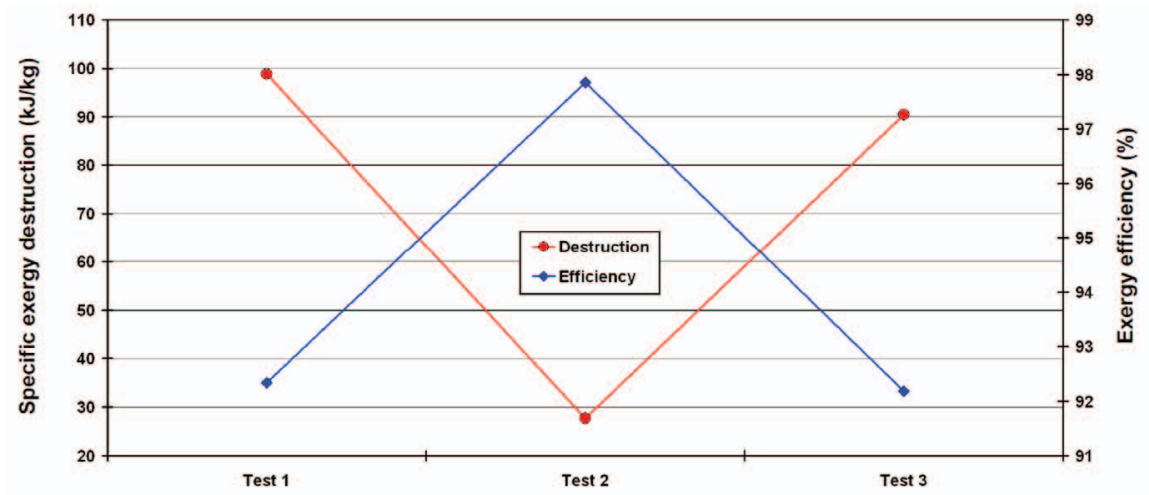

Fig. 6 Labyrinth seals specific exergy destruction and exergy efficiency for three observed tests Source: Authors

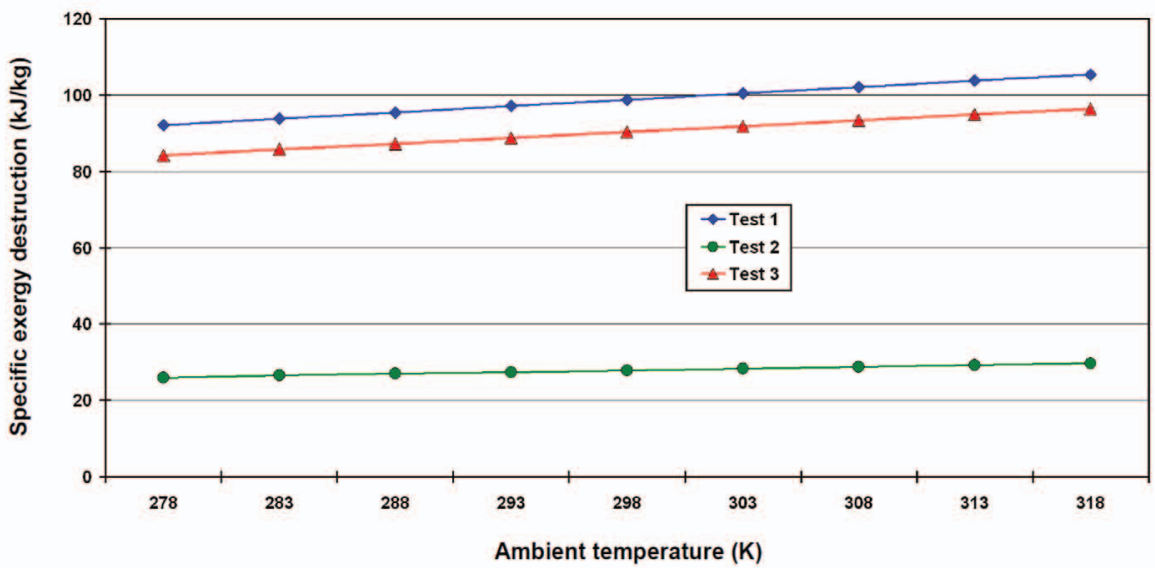

Fig. 7 Labyrinth seals specific exergy destruction during the ambient temperature change for three observed tests Source: Authors

For all of the observed tests, it can be concluded that an increase in the ambient temperature increases labyrinth seals specific exergy destruction, Fig. 7. The ambient temperature change has the highest influence on labyrinth seals specific exergy destruction in Test 1 (where the steam pressure decrease is the highest). In the observed ambient temperature range (from $278 \mathrm{~K}$ to $318 \mathrm{~K}$ ), change of seals specific exergy destruction for Test 1 amounts $13.20 \mathrm{~kJ} /$ $\mathrm{kg}$ (from $92.20 \mathrm{~kJ} / \mathrm{kg}$ to $105.40 \mathrm{~kJ} / \mathrm{kg}$ ), while in the same ambient temperature range change of seals specific exergy destruction is the lowest for Test 2 and amounts $3.70 \mathrm{~kJ} / \mathrm{kg}$ (from $25.90 \mathrm{~kJ} / \mathrm{kg}$ to $29.60 \mathrm{~kJ} / \mathrm{kg}$ ). Analyzed labyrinth seals specific exergy destruction is also highly influenced by the ambient temperature change in Test 3 and amounts 12.12 $\mathrm{kJ} / \mathrm{kg}$ (from $84.30 \mathrm{~kJ} / \mathrm{kg}$ to $96.42 \mathrm{~kJ} / \mathrm{kg}$ ), between the ambient temperatures of $278 \mathrm{~K}$ and $318 \mathrm{~K}$, Fig. 7.

An increase in the ambient temperature, for all of the observed tests, shows that analyzed labyrinth seals 


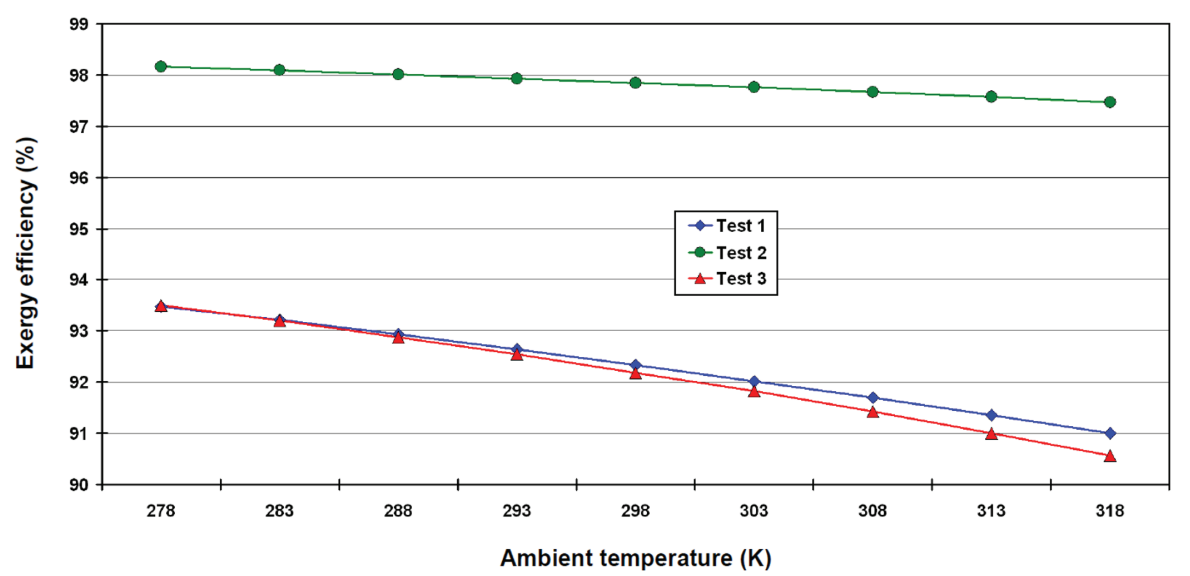

Fig. 8 Labyrinth seals exergy efficiency during the ambient temperature change for three observed tests Source: Authors

exergy efficiency is reverse proportional to specific exergy destruction - seals exergy efficiency decreases during the increase in the ambient temperature, Fig. 8. The ambient temperature change from $278 \mathrm{~K}$ to $318 \mathrm{~K}$ shows the highest influence on labyrinth seals exergy efficiency in Test 3 where the cumulative change is equal to $2.93 \%$ (from $93.50 \%$ to $90.57 \%$ ). Labyrinth seals exergy efficiency in Test 1 is also highly influenced by the change in the ambient temperature - in the observed ambient temperature range the cumulative change in seals exergy efficiency for Test 1 is $2.48 \%$ (from $93.47 \%$ to $91.00 \%$ ), while in the same ambient temperature range seals exergy efficiency is the lowest influenced in Test 2 - cumulative change is $0.69 \%$ (from $98.17 \%$ to $97.48 \%$ ), Fig. 8 .

In the observed ambient temperature range in which can be expected the majority of analyzed labyrinth seals operation, change in seals exergy efficiency is not significant and for all observed operating regimes seals exergy efficiency did not fall below $90.5 \%$.

\section{Conclusions}

This paper presents an exergy analysis of steam labyrinth (gland) seals, which are an inevitable component of any steam turbine cylinder. Based on known steam operating parameters at analyzed labyrinth seals inlet and outlet, performed exergy analysis gives the following main conclusions:

- Steam specific enthalpy at the labyrinth seals inlet and outlet can be considered as a constant, because the results obtained by this assumption do not deviate significantly from the results of complex numerical models which involve a change of steam specific enthalpy through the labyrinth seals.

- Labyrinth seals, simultaneously with a steam pressure decrease cause decrease in steam temperature.

- Change in steam specific entropy difference (between seals outlet and inlet) is proportional to the change in seals specific exergy destruction.
- Changes in labyrinth seals exergy efficiency and specific exergy destruction are reverse proportional.

- Analyzed labyrinth seals have high exergy efficiencies in each observed operating regime at the ambient temperature of $298 \mathrm{~K}$ (above 92\%), what indicates seals proper operation.

- An increase in the ambient temperature resulted with an increase in labyrinth seals specific exergy destruction and simultaneously with a decrease in seals exergy efficiency.

- Even at the highest observed ambient temperature $(318 \mathrm{~K})$, exergy efficiency of the analyzed labyrinth seals, in each observed operating regime, did not fall below $90.5 \%$.

Presented analysis is not applicable only for the investigated steam labyrinth (gland) seals, the same equations and procedure can be used for the analysis of any labyrinth seal - if the operating medium parameters (pressure and temperature) at the seal inlet and outlet are known. Therefore, such analysis can be a good indicator of any labyrinth seal (or a group of labyrinth seals) proper or unproper operation.

\section{Acknowledgment}

This research has been supported by the Croatian Science Foundation under the project IP-2018-01-3739, CEEPUS network CIII-HR-0108, European Regional Development Fund under the grant KK.01.1.1.01.0009 (DATACROSS) and University of Rijeka scientific grant uniri-tehnic-18-275-1447.

\section{References}

[1] Mrzljak, V., Poljak, I.: Energy Analysis of Main Propulsion Steam Turbine from Conventional LNG Carrier at Three Different Loads, International Journal of Maritime Science \& Technology “Our Sea” 66 (1), p. 10-18, 2019. (doi:10.17818/ NM/2019/1.2) 
[2] Mrzljak, V., Poljak, I., Medica-Viola, V.: Energy and Exergy Efficiency Analysis of Sealing Steam Condenser in Propulsion System of LNG Carrier, International Journal of Maritime Science \& Technology "Our Sea" 64 (1), p. 20-25, 2017. (doi:10.17818/NM/2017/1.4)

[3] Blažević, S., Mrzljak, V., Anđelić, N., Car, Z.: Comparison of energy flow stream and isentropic method for steam turbine energy analysis, Acta Polytechnica 59 (2), p. 109-125, 2019. (doi:10.14311/AP.2019.59.0109)

[4] Mrzljak, V.: Low power steam turbine energy efficiency and losses during the developed power variation, Technical Journal 12 (3), p. 174-180, 2018. (doi:10.31803/tg20180201002943)

[5] Sutton, I.: Plant Design and Operations, Elsevier Inc., 2015.

[6] Mrzljak, V., Poljak, I., Prpić-Oršić, J.: Exergy analysis of the main propulsion steam turbine from marine propulsion plant, Shipbuilding: Theory and Practice of Naval Architecture, Marine Engineering and Ocean Engineering 70 (1), p. 59-77, 2019. (doi:10.21278/brod70105)

[7] Marine Steam Turbine MS40-2 - Instruction Book For Marine Turbine Unit, HYUNDAI-MITSUBISHI, HYUNDAI HEAVY INDUSTRIES CO., LTD., ULSAN, KOREA, 2004., internal ship documentation

[8] Kostyuk, A., Frolov, V.: Steam and gas turbines, Mir Publishers, Moscow, 1988.

[9] Cangioli, F., Chatterton, S., Pennacchi, P., Nettis, L., Ciuchicchi, L.: Thermo-elasto bulk-flow model for labyrinth seals in steam turbines, Tribology International 119, p. 359-371, 2018. (doi:10.1016/j.triboint.2017.11.016)

[10] Tan, H., Shan, S., Nie, Y., Zhao, Q.: A new boil-off gas re-liquefaction system for $L N G$ carriers based on dual mixed refrigerant cycle, Cryogenics 92, p. 84-92, 2018. (doi:10.1016/j. cryogenics.2018.04.009)

[11] Mrzljak, V., Poljak, I., Žarković, B.: Exergy Analysis of Steam Pressure Reduction Valve in Marine Propulsion Plant on Conventional LNG Carrier, International Journal of Maritime Science \& Technology “Our Sea” 65 (1), p. 24-31, 2018. (doi:10.17818/NM/2018/1.4)

[12] Regulagadda, P., Dincer, I., Naterer, G. F.: Exergy analysis of a thermal power plant with measured boiler and turbine losses, Applied Thermal Engineering 30, p. 970-976, 2010. (doi:10.1016/j.applthermaleng.2010.01.008)

[13] Medica-Viola, V., Pavković, B., Mrzljak, V.: Numerical model for on-condition monitoring of condenser in coal-fired power plants, International Journal of Heat and Mass Transfer 117, p. 912-923, 2018. (doi:10.1016/j.ijheatmasstransfer.2017.10.047)

[14] Mrzljak, V., Senčić, T., Žarković, B.: Turbogenerator Steam Turbine Variation in Developed Power: Analysis of Exergy Efficiency and Exergy Destruction Change, Modelling and Simulation in Engineering 2018. (doi:10.1155/2018/2945325)

[15] Naserbegi, A., Aghaie, M., Minuchehr, A., Alahyarizadeh, Gh.: A novel exergy optimization of Bushehr nuclear power plant by gravitational search algorithm (GSA), Energy 148, p. 373-385, 2018. (doi:10.1016/j.energy.2018.01.119)

[16] Mrzljak, V., Poljak, I., Medica-Viola, V.: Dual fuel consumption and efficiency of marine steam generators for the propulsion of $L N G$ carrier, Applied Thermal Engineering 119, p. 331-346, 2017. (doi:10.1016/j.applthermaleng.2017.03.078)
[17] Mrzljak, V., Prpić-Oršić, J., Senčić, T.: Change in Steam Generators Main and Auxiliary Energy Flow Streams During the Load Increase of LNG Carrier Steam Propulsion System, Scientific Journal of Maritime Research 32 (1), p. 121-131, 2018. (doi:10.31217/p.32.1.15)

[18] Ahmadi, G. R., Toghraie, D.: Energy and exergy analysis of Montazeri Steam Power Plant in Iran, Renewable and Sustainable Energy Reviews 56, p. 454-463, 2016. (doi:10.1016/j.rser.2015.11.074)

[19] Poljak, I., Orović, J., Mrzljak, V.: Energy and Exergy Analysis of the Condensate Pump During Internal Leakage from the Marine Steam Propulsion System, Scientific Journal of Maritime Research 32 (2), p. 268-280, 2018. (doi:10.31217/p.32.2.12)

[20] Noroozian, A., Mohammadi, A., Bidi, M., Ahmadi, M. H.: Energy, exergy and economic analyses of a novel system to recover waste heat and water in steam power plants, Energy Conversion and Management 144, p. 351-360, 2017. (doi:10.1016/j.enconman.2017.04.067)

[21] Koroglu, T., Sogut, O. S.: Advanced exergy analysis of an organic Rankine cycle waste heat recovery system of a marine power plant, Journal of Thermal Engineering 3 (2), p. 1136-1148, 2017. (doi:10.18186/thermal.298614)

[22] Mrzljak, V., Poljak, I., Medica-Viola, V.: Thermodynamical analysis of high-pressure fed water heater in steam propulsion system during exploitation, Shipbuilding: Theory and Practice of Naval Architecture, Marine Engineering and Ocean Engineering 68 (2), p. 45-61, 2017. (doi:10.21278/ brod68204)

[23] Mrzljak, V., Poljak, I., Mrakovčić, T.: Energy and exergy analysis of the turbo-generators and steam turbine for the main feed water pump drive on LNG carrier, Energy Conversion and Management 140, p. 307-323, 2017. (doi:10.1016/j. enconman.2017.03.007)

[24] Adibhatla, S., Kaushik, S. C.: Energy and exergy analysis of a super critical thermal power plant at various load conditions under constant and pure sliding pressure operation, Applied Thermal Engineering 73, p. 49-63, 2014. (doi:10.1016/j.applthermaleng.2014.07.030)

[25] Orović, J., Mrzljak, V., Poljak, I.: Efficiency and Losses Analysis of Steam Air Heater from Marine Steam Propulsion Plant, Energies 2018, 11 (11), 3019, (doi:10.3390/en11113019)

[26] Baldi, F., Ahlgren, F., Van Nguyen, T., Thern, M., Andersson, K.: Energy and Exergy Analysis of a Cruise Ship, Energies 2018, 11, 2508, (doi:10.3390/en11102508)

[27] Baldi, F., Johnson, H., Gabrielii, C., Andersson, K.: Energy and Exergy Analysis of Ship Energy Systems - The Case study of a Chemical Tanker, International Journal of Thermodynamics 18 (2), p. 82-93, 2015. (doi:10.5541/ijot.70299)

[28] Koroglu, T., Sogut, O. S.: Conventional and Advanced Exergy Analyses of a Marine Steam Power Plant, Energy 163, p. 392-403, 2018. (doi:10.1016/j.energy.2018.08.119)

[29] Lemmon, E.W., Huber, M.L., McLinden, M.O.: NIST reference fluid thermodynamic and transport properties-REFPROP, version 9.0, User's guide, Colorado, 2010.

[30] Mrzljak, V., Poljak, I., Medica-Viola, V.: Efficiency and losses analysis of low-pressure feed water heater in steam propulsion system during ship maneuvering period, Scientific Journal of Maritime Research 30, p. 133-140, 2016. (doi:10.31217/p.30.2.6) 